\title{
EFEKTIVITAS Pseudomonas sp. BOT4 DALAM MENDEGRADASI MINYAK JELANTAH MENGGUNAKAN SUMBER NITROGEN NATRIUM NITRAT DAN YEAST EXTRACT
}

\author{
Donatus Tia Harfan'1, Diah Wulandari Rousdy ${ }^{1}$, Rikhsan Kurniatuhadi ${ }^{1}$ \\ ${ }^{1}$ Program Studi Biologi, Fakultas Matematika dan Ilmu Pengetahuan Alam, Universitas Tanjungpura, \\ Jl. Prof. Dr. H. Hadari Nawawi, Pontianak \\ e-mail koresponden: donharfan@gmail.com
}

\begin{abstract}
Jelantah is the residual waste of cooking oil. The disposal of untreated waste directly into the environment has the potential to promote damage such as water channels clogging and water body pollution. Form of waste treatment such as biodegradation can be done using potential bacteria such as Pseudomonas spp. which has been known for being effectively in decomposing organic waste. This study aimed to observe the ability of Pseudomonas sp. BOT4 in degrading jelantah with different nitrogen sources i.e. $\mathrm{NaNO}_{3}$ and yeast extract. This study was carried out from August to October 2018. The used cooking oil samples were homemade with deep frying method and the isolate samples were collected from used cooking oil-contaminated sewer water. Split plot design was used with time of incubation as main plots and nitrogen sources as subplots. The parameters observed were cell density and degraded oil weight. The results obtained stated that nitrogen sources of $\mathrm{NaNO}_{3}$ and yeast extract given optimum effect on cell density of Pseudomonas sp. BOT4 on day three each with $\mathrm{OD}_{600}$ value of 1,361 and 2,300. Nevertheless both nitrogen sources did not really give real effect on final weight of degraded oil, each with weight of $1,28 \mathrm{~g}$ dan $1,09 \mathrm{~g}$.
\end{abstract}

Keywords: jelantah, Pseudomonas sp. BOT4, nitrogen sources, cell density, degraded oil weight

\section{PENDAHULUAN}

Minyak goreng merupakan salah satu kebutuhan pokok yang sering dikonsumsi oleh masyarakat, baik dalam skala rumah tangga maupun industri (Ramdja et al., 2010). Sebagian besar minyak goreng yang beredar di Indonesia berasal dari minyak sawit mentah (crude palm oil/ CPO) dan minyak kelapa mentah (crude coconut oil/ $\mathrm{CCO}$ ) (Daulay \& Madya, 2015). Nilai konsumsi minyak goreng di Indonesia pada tahun 2014 sebesar 9,604 liter/kapita/tahun meningkat pada tahun 2015 menjadi 11,211 liter/kapita/tahun (Pusat Data dan Sistem Informasi Pertanian, 2015). Nilai ini diperkirakan akan terus meningkat setiap tahun seiring pertumbuhan penduduk dan industri perkebunan kelapa sawit di Indonesia. Peningkatan tersebut pada akhirnya akan berdampak pada peningkatan volume minyak jelantah sebagai limbah habis pakai.

Limbah minyak jelantah yang terbuang ke lingkungan perairan dapat menimbulkan pencemaran. Pencemaran terjadi akibat terbentuknya lapisan minyak di permukaan air sehingga menghambat kelarutan oksigen dalam air dan mengganggu organisme di dalam dan sekitarnya. Oleh karena itu, diperlukan metode penanganan limbah minyak jelantah yang ramah lingkungan (Lessard \& Le Bihan, 2003). Salah satu metode tersebut yaitu biodegradasi dengan bakteri potensial. Bakteri yang digunakan harus mempunyai fisiologi dan metabolik untuk mendegradasi bahan pencemar (Noegroho, 1999).

Bakteri Pseudomonas spp. yang termasuk ke dalam genus Pseudomonas diketahui mampu menggunakan substrat organik seperti minyak sayur untuk pertumbuhannya (Brenner et al., 2005; Boulton \& Ratledge, 1987). Salah satu anggota genus Pseudomonas yaitu Pseudomonas aeruginosa mampu menggunakan lebih dari 75 macam bahan organik sebagai sumber karbon baik melalui respirasi aerob maupun anaerob (Todar, 2004). Kemampuan Pseudomonas aeruginosa dalam aktivitas biodegradasi dipengaruhi nutrien yang digunakan dalam medium pertumbuhannya seperti sumber nitrogen. Nitrogen bersifat krusial dalam produksi biosurfaktan yang berkaitan dengan sintesis protein dan enzim pertumbuhannya (Amaral et al., 2008). Optimasi produksi dari biosurfaktan oleh Pseudomonas aeruginosa terjadi melalui mekanisme limitasi nitrogen dengan rasio karbon/ 
nitrogen $(\mathrm{C} / \mathrm{N})$ tertentu yang meningkatkan produksi biosurfaktan.

Nitrogen yang umum digunakan dalam produksi biosurfaktan oleh bakteri salah satunya Pseudomonas aeruginosa yaitu yeast extract (Amaral et al., 2008). Biosurfaktan yang dihasilkan berfungsi untuk menurunkan tegangan permukaan minyak melalui proses pemecahan emulsi sehingga minyak dapat larut dalam air. Penelitian Wu et al. (2008) dan Moussa et al. (2014) menunjukkan pengaruh yang lebih signifikan dalam degradasi minyak bumi oleh $P$. aeruginosa ditunjukkan dari pengunaan natrium nitrat dibandingkan dengan amonium nitrat dan amonium sulfat sebagai sumber nitrogen anorganik. Hasil-hasil penelitian di atas menjadi dasar penelitian ini dilakukan dalam minyak jelantah untuk melihat efektivitas degradasi yang terjadi terutama dengan penggunaan natrium nitrat dan yeast extract sebagai sumber nitrogen oleh Pseudomonas sp. BOT4.

\section{BAHAN DAN METODE}

Penelitian dilaksanakan dari Agustus hingga Oktober 2018 di Laboratorium Mikrobiologi dan di Laboratorium Kimia Fakultas Matematika dan Ilmu Pengetahuan Alam Universitas Tanjungpura Pontianak.

Bahan-bahan yang digunakan yaitu alkohol 70\%, akuades, dichloromethane (DCM) teknis, isolat Pseudomonas sp. BOT4, media: agar DNase, Cetrimide, gelatinase, okisdasi/fermentasi (O/F), lipolitik, Tryptone Soya Agar (TSA), metil merah, minyak jelantah, minyak zaitun steril, $\mathrm{NaCl} 0,85 \%$, pepton, standar 0,5 McFarland, tween-80, $\mathrm{CaCl}_{2} .2 \mathrm{H}_{2} \mathrm{O}, \quad$ agar, $\quad \mathrm{KH}_{2} \mathrm{PO}_{4}, \quad \mathrm{Na}_{2} \mathrm{HPO}_{4}$, $\mathrm{MgSO}_{4} .7 \mathrm{H}_{2} \mathrm{O}, \mathrm{FeSO}_{4} .7 \mathrm{H}_{2} \mathrm{O}$, dan sumber nitrogen natrium nitrat $\left(\mathrm{NaNO}_{3}\right)$ dan yeast extract.

\section{Rancangan Percobaan}

Rancangan percobaan dalam penelitian ini yaitu Rancangan Petak Terbagi (RPT). Penelitian dilakukan untuk melihat peran sumber nitrogen $\left(\mathrm{NaNO}_{3}\right.$ dan yeast extract) dan waktu inkubasi (hari ke-0, 1, 2, 3, 4) terhadap kepadatan sel bakteri Pseudomonas sp. BOT4 dan berat minyak terdegradasi.

Lima taraf lama inkubasi merupakan petak utama (main plots) dan tiga taraf perlakuan (termasuk kontrol/ tanpa sumber nitrogen) merupakan anak petak (sub plots) dan sehingga terdapat 15 kombinasi perlakuan yang diulang sebanyak tiga kali dan diperoleh 45 unit percobaan.
Pengambilan Sampel Isolasi Pseudomonas spp. dan Minyak Jelantah

Sampel untuk isolasi Pseudomonas sp. adalah air yang diambil dari parit tercemar minyak jelantah di dekat kios penjual ayam goreng tepi jalan. Sampel air diambil sebanyak $100 \mathrm{~mL}$ dan dimasukkan ke dalam botol kaca steril.

Sampel minyak jelantah dibuat di rumah menggunakan metode deep frying dengan tiga kali penggorengan dan diambil sebanyak $500 \mathrm{~mL}$. Sampel disaring terlebih dahulu dari sisa-sisa penggorengan sebelum dimasukkan ke dalam botol kaca steril lalu disterilisasi.

Isolasi Pseudomonas spp.

Sampel air diencerkan pada lima laju pengenceran $\left(10^{-1}, 10^{-2}, 10^{-3}, 10^{-4}, 10^{-5}\right)$ lalu dituang ke dalam cawan Petri yang telah berisi medium TSA. Cawan diinkubasi pada suhu $37^{\circ} \mathrm{C}$ selama 24 jam. Setelah 24 jam, diambil masing-masing satu koloni yang tumbuh pada laju pengenceran $10^{-4}$ dan $10^{-5}$ untuk diidentifikasi menurut acuan oleh Lysenko (1961). Koloni yang teridentifikasi sebagai Pseudomonas spp. dikultur ke dalam medium selektif Cetrimide dan diinkubasi selama 2x24 jam. Koloni yang tumbuh lalu direkultur ke dalam medium TSA dan disimpan pada suhu $4{ }^{\circ} \mathrm{C}$ sebelum uji selanjutnya (Silva et al., 2006).

\section{Uji Gelatinase}

Uji gelatinase dilakukan dengan menginokulasi bakteri ke dalam tabung reaksi yang berisi medium gelatin. Tabung diinkubasi pada suhu $37^{\circ} \mathrm{C}$ selama 24 jam sebelum dimasukkan ke dalam lemari es $\left( \pm 4^{\circ} \mathrm{C}\right)$ selama $10-15$ menit. Reaksi positif ditunjukkan jika medium gelatin tetap mencair setelah dimasukkan ke dalam lemari es.

\section{Uji Kualitatif Lipolitik Pseudomonas sp. BOT4}

Uji kualitatif aktivitas lipolitik dimodifikasi dari metode Bestari \& Suharjono (2015). Isolat dikultur terpisah selama 24 jam dalam tabung reaksi yang berisi $5 \mathrm{~mL}$ media preparasi cair yang dibuat dengan komposisi: $1 \% \mathrm{NaCl}, 1 \%$ yeast extract, $2 \%$ pepton, $1 \%$ tween-80, dan $2 \%$ minyak zaitun steril.

Kertas cakram berdiameter $\pm 5 \mathrm{~mm}$ dicelupkan ke dalam media cair di atas selama 24 jam. Kemudian kertas diletakkan dalam cawan Petri yang telah berisi media uji padat yang dibuat dengan komposisi per liter: $10 \mathrm{~g}$ pepton, $5 \mathrm{~g} \mathrm{NaCl}, 0,1 \mathrm{~g} \mathrm{CaCl} .2 \mathrm{H}_{2} \mathrm{O}$, $20 \mathrm{~g}$ agar, $2,5 \%$ tween- $80,5 \%$ minyak zaitun steril, dan $0,01 \%$ metil merah. Cawan diinkubasi selama 2x24 jam lalu diukur indeks lipolitiknya dan isolat dengan indeks tertinggi dijadikan sebagai kultur inokulum dan diberi kode isolat BOT4. 


\section{Kultur Inokulum Pseudomonas sp. BOT4}

Kultur inokulum dibuat dengan memasukkan satu loop kultur koloni Pseudomonas sp. BOT4 ke dalam

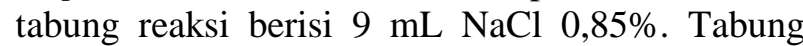
dikocok dan disetarakan kekeruhannya dengan larutan standar 0,5 McFarland.

Larutan standar 0,5 McFarland dibuat dalam tabung reaksi dengan mencampurkan $0,5 \mathrm{~mL} \mathrm{BaCl}_{2} 1 \%$ dan $9,5 \mathrm{~mL} \mathrm{H}_{2} \mathrm{SO}_{4} 1 \%$ (Dalynn Biologicals, 2014).

Uji Degradasi Minyak Jelantah oleh Pseudomonas sp. BOT4

Uji degradasi dilakukan menurut metode oleh Subasioglu \& Cansunar (2008) dalam medium basal (MB) dengan komposisi (g/L): $\mathrm{KH}_{2} \mathrm{PO}_{4}(0,7)$, $\mathrm{Na}_{2} \mathrm{HPO}_{4}$ (2), $\mathrm{CaCl}_{2} \cdot 2 \mathrm{H}_{2} \mathrm{O}(0,01), \mathrm{MgSO}_{4} \cdot 7 \mathrm{H}_{2} \mathrm{O}$ $(0,4)$, dan $\mathrm{FeSO}_{4} .7 \mathrm{H}_{2} \mathrm{O}(0,001)$. Dua unit perlakuan sumber nitrogen: 0,25 gr $\mathrm{NaNO}_{3}$ dan 0,25 gr yeast extract masing-masing dibuat di dalam $50 \mathrm{~mL}$ medium ditambah $2 \mathrm{~mL}$ inokulum bakteri dan $5 \mathrm{~g}$ minyak jelantah. Satu unit kontrol dibuat tanpa sumber nitrogen. Seluruhnya dibuat dalam labu Erlenmeyer untuk diinkubasi dalam shaker orbital dengan kecepatan $150 \mathrm{rpm}$ pada suhu $30^{\circ} \mathrm{C}$ selama 4 hari. Pengulangan dilakukan tiga kali. Rasio karbon/nitrogen $(\mathrm{C} / \mathrm{N})$ yang digunakan 20:1.

Pengukuran Kepadatan Sel Pseudomonas sp. BOT4 Pengukuran absorbansi sel Pseudomonas sp. BOT4 dilakukan dengan mengamati nilai optical density (OD) tiap labu seluruh perlakuan pada panjang gelombang $600 \mathrm{~nm}$ menggunakan spektrofotometer UV-Vis. Pengukuran dilakukan setiap hari selama 4 hari berturut-turut dan hasilnya dibuat kurva (Mulligan \& Gibbs, 1989).

\section{Pengukuran Berat Minyak Jelantah Terdegradasi} Ekstraksi berdasarkan analisis gravimetri dengan mengukur residu minyak setiap unit perlakuan per hari selama empat hari berturut. Isi labu dituang ke dalam tabung sentrifus dan disentrifugasi pada kecepatan $10.000 \mathrm{rpm}$ selama 50 menit. Hasil sentrifugasi ditambahkan $40 \mathrm{~mL}$ DCM dan diguncang dalam corong pemisah sehingga didapatkan lapisan organik pada bagian bawah corong. Lapisan dimasukkan ke dalam labu untuk dipanaskan dalam waterbath pada suhu $60{ }^{\circ} \mathrm{C}$ selama 5 hari untuk menguapkan DCM. Residu minyak yang tertinggal kemudian ditimbang dan dihitung selisihnya dengan berat labu awal (Bharathi et al., 2012).

\section{Analisis Data}

Data hasil pengukuran berupa kepadatan sel bakteri dan hasil degradasi minyak minyak jelantah ditabulasi dalam Microsoft Excel 2013. Selanjutnya data dianalisis dengan ANAVA univariat menggunakan PASW Statistics 18 dan dilanjutkan dengan Uji Tukey dengan taraf signifikansi 5\%.

\section{HASIL DAN PEMBAHASAN}

\section{Hasil}

\section{Isolasi Pseudomonas sp. BOT4}

Pseudomonas sp. BOT4 yang diisolasi dari lingkungan tercemar minyak jelantah merupakan isolat yang memiliki aktivitas lipolitik terbesar. Berikut ini karakteristik isolat Pseudomonas sp. BOT4 yang diperoleh melalui beberapa uji determinasi berdasarkan Brenner et al. (2005).

Tabel 1. Karakteristik Pseudomonas sp. BOT4

\begin{tabular}{cc}
\hline Karakteristik & Hasil \\
\hline Tumbuh di suhu $41{ }^{\circ} \mathrm{C}$ & + \\
Menghasilkan gelatinase & + \\
Lipolitik & + \\
\hline
\end{tabular}

Hasil pengamatan (Gambar 1) menunjukkan isolat memiliki ciri bulat, putih agak transparan, rata, dengan tepi agak tidak rata dan pusat yang agak mengerucut (a), Gram negatif dengan bentuk batang dan panjang 1-3 $\mu \mathrm{m}$ (b), dan memiliki indeks lipolitik 12,91 berdasarkan diameter zona bening yang terbentuk (c).

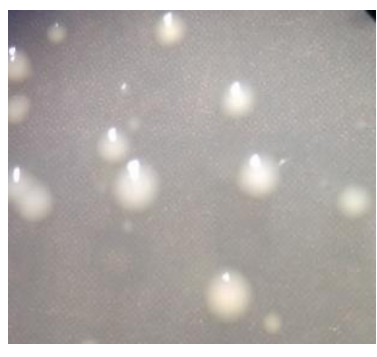

(a)

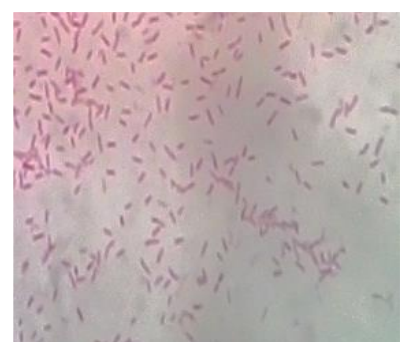

(b)

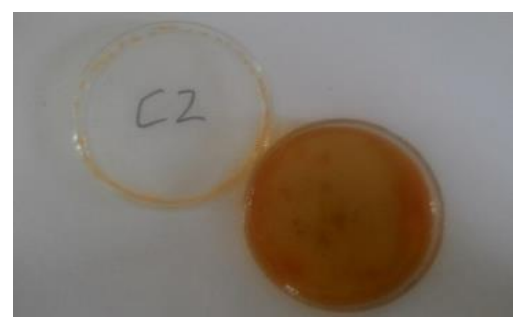

(c)

Gambar 1. Hasil Pengamatan Pseudomonas sp. BOT4 Morfologi Koloni (a), Morfologi Sel (perbesaran 1000x) (b), Uji Lipolitik (c) 


\section{Kepadatan Sel Pseudomonas sp. BOT4}

Kepadatan sel digambarkan dalam OD (optical density) dalam panjang gelombang $600 \mathrm{~nm}\left(\mathrm{OD}_{600}\right)$. Asumsi yang digunakan yaitu semakin tinggi nilai OD maka semakin tinggi kepadatan sel.

Pada Tabel 2 dapat dilihat bahwa antara seluruh perlakuan relatif tidak terdapat perbedaan nyata pada hari pertama dan kedua pengukuran.
Akan tetapi pada hari ketiga dan keempat pengukuran antara perlakuan yeast extract dan dua perlakuan lain (kontrol dan $\mathrm{NaNO}_{3}$ ) terdapat perbedaan nyata terutama pada hari ketiga saat penggunaan yeast extract menghasilkan nilai $\mathrm{OD}_{600}$ tertinggi. Hal ini menunjukkan bahwa penambahan nitrogen terutama yeast extract berpengaruh signifikan terhadap peningkatan kepadatan sel dalam empat hari pengujian.

Tabel 2. Kepadatan Sel (OD 600 Seluruh Perlakuan)

\begin{tabular}{ccccc}
\hline \multirow{2}{*}{ Perlakuan } & \multicolumn{4}{c}{ Kepadatan Sel $\left(\mathbf{O D}_{600}\right)$} \\
\cline { 2 - 4 } & $\mathbf{1}$ & $\mathbf{2}$ & $\mathbf{3}$ & $\mathbf{4}$ \\
\cline { 2 - 4 } & $0,365 \pm 0,198^{\mathrm{a}}$ & $0,493 \pm 0,257^{\mathrm{ab}}$ & $0,907 \pm 0,132^{\mathrm{abc}}$ & $0,842 \pm 0,009^{\mathrm{abc}}$ \\
Kontrol & $0,105 \pm 0,681^{\mathrm{a}}$ & $1,008 \pm 0,669^{\mathrm{abc}}$ & $1,361 \pm 1,133^{\mathrm{abc}}$ & $0,899 \pm 1,353^{\mathrm{abc}}$ \\
Yeast extract & $0,404 \pm 0,223^{\mathrm{a}}$ & $0,992 \pm 0,664^{\mathrm{abc}}$ & $2,300 \pm 0,212^{\mathrm{c}}$ & $2,009 \pm 0,143^{\mathrm{bc}}$ \\
\hline
\end{tabular}

Keterangan: Nilai yang diikuti pangkat sama menunjukan tidak ada pengaruh nyata setelah dilanjutkan dengan Uji Tukey $(\alpha=0,05)$.

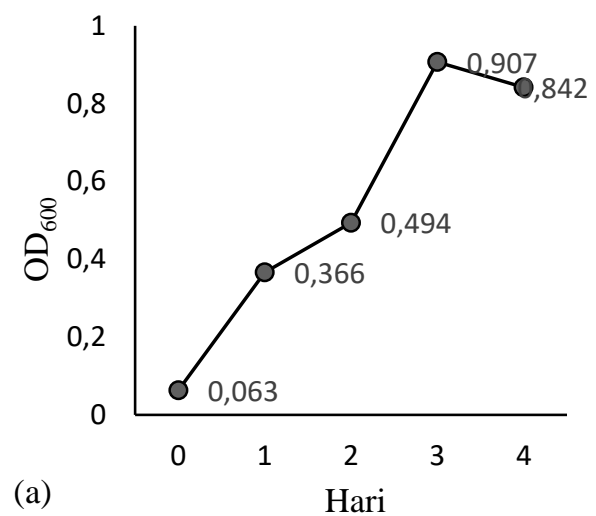

(a)

Hari

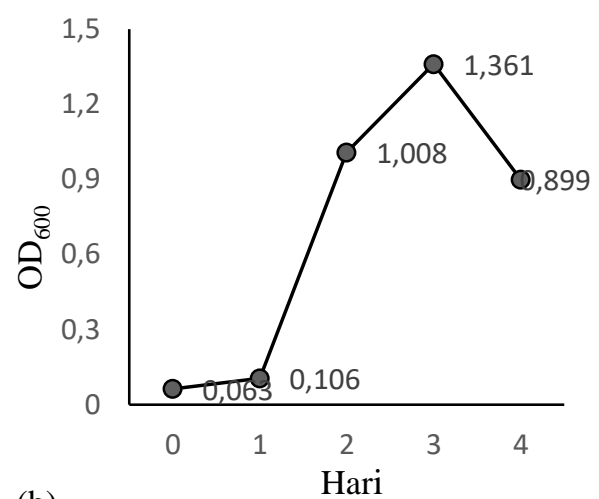

(b)

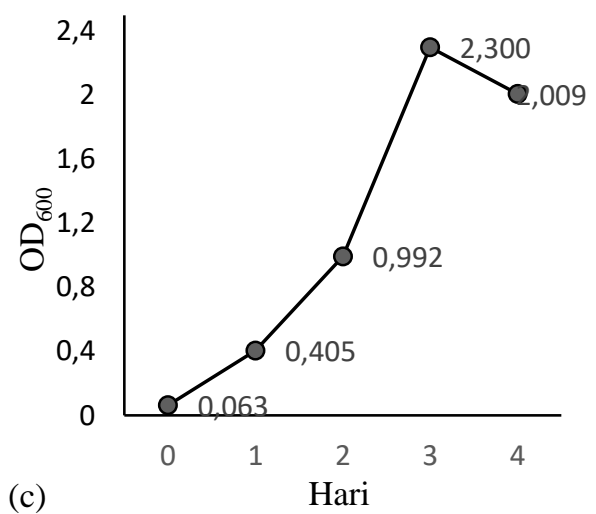

Gambar 2. Kurva Kepadatan Sel Tiap Perlakuan Kontrol (a), $\mathrm{NaNO}_{3}$ (b), Yeast extract (c) 
Gambar 2 menggambarkan kecenderungan peningkatan kepadatan sel bakteri dalam empat hari pengujian. Secara umum dapat dilihat bahwa pada setiap perlakuan terjadi peningkatan kepadatan sel secara linier mulai dari hari pertama sampai hari ketiga hingga terjadi penurunan pada hari keempat. Kepadatan sel meningkat secara bertahap dalam dua hari pertama pada seluruh perlakuan meskipun pada $\mathrm{NaNO}_{3}$ terjadi peningkatan yang cukup lambat pada hari pertama yang diikuti peningkatan yang cukup tinggi pada hari kedua. Seluruh perlakuan mengalami puncak peningkatan kepadatan sel pada hari ketiga dan menurun pada hari keempat.

\section{Berat Minyak Jelantah Terdegradasi}

Nilai residu minyak berbanding lurus dengan efektivitas perlakuan. Semakin banyak minyak yang terdegradasi maka semakin efektif perlakuan yang diberikan.

Tabel 3. Berat Minyak Jelantah Terdegradasi

\begin{tabular}{|c|c|c|c|c|}
\hline \multirow{3}{*}{ Perlakuan } & \multicolumn{4}{|c|}{ Berat Minyak Terdegradasi (g) } \\
\hline & \multicolumn{4}{|c|}{ Waktu Inkubasi (hari) } \\
\hline & 1 & 2 & 3 & 4 \\
\hline Kontrol & $0,66 \pm 0,85^{\mathrm{a}}$ & $1,15 \pm 0,14^{\text {abcde }}$ & $1,34 \pm 0,13^{\mathrm{de}}$ & $1,56 \pm 0,17^{\mathrm{e}}$ \\
\hline $\mathrm{NaNO}_{3}$ & $0,79 \pm 0,46^{\mathrm{abc}}$ & $1,15 \pm 0,08^{\text {abcde }}$ & $1,20 \pm 0,09^{\text {bcde }}$ & $1,28 \pm 0,09^{\text {cde }}$ \\
\hline Yeast extract & $0,71 \pm 0,25^{\mathrm{ab}}$ & $0,82 \pm 0,36^{\mathrm{abc}}$ & $0,93 \pm 0,31^{\mathrm{abcd}}$ & $1,09 \pm 0,25^{\text {abcde }}$ \\
\hline
\end{tabular}

Keterangan: Nilai yang diikuti pangkat sama menunjukan tidak ada pengaruh nyata setelah dilanjutkan dengan Uji Tukey $(\alpha=0,05)$.

Tabel 3 secara umum menunjukkan relatif tidak ada pengaruh signifikan yang diberikan dari penggunaan sumber nitrogen $\left(\mathrm{NaNO}_{3}\right.$ dan yeast extract) dibandingkan tanpa penggunaan sumber nitrogen (kontrol) terhadap berat minyak terdegradasi. Hal tersebut ditunjukkan dengan berat minyak pada akhir pengamatan yang lebih baik dihasilkan pada perlakuan kontrol dibandingkan perlakuan $\mathrm{NaNO}_{3}$ dan yeast extract. Adapun perlakuan yeast extract efektif hanya pada hari pertama.

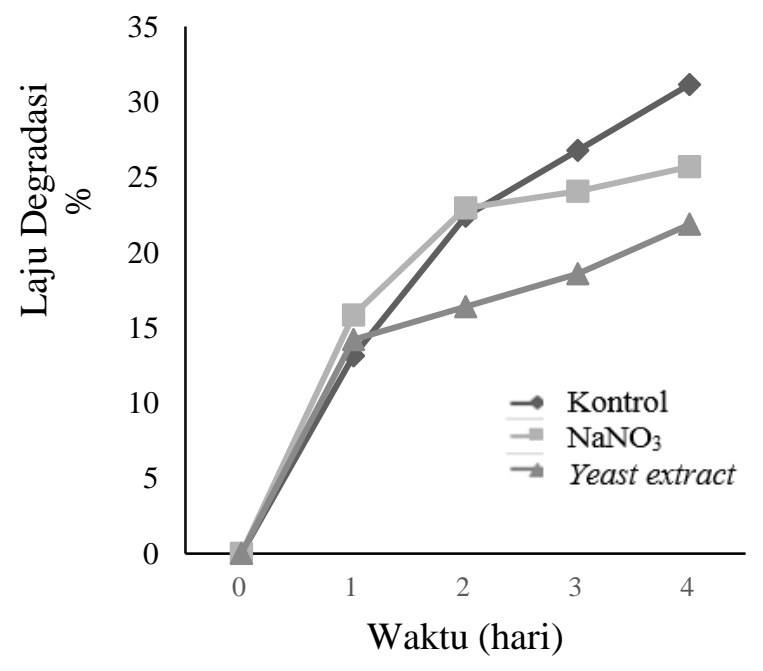

Gambar 3. Laju Degradasi Minyak Jelantah Seluruh Perlakuan $(\%)$
Gambar 3 menyatakan bahwa laju degradasi seluruh perlakuan secara umum cenderung naik. Laju biodegradasi pada hari ke-1 relatif tidak berbeda jauh antar perlakuan dengan selisih 1-2\% dengan laju tertinggi berada pada perlakuan $\mathrm{NaNO}_{3}$. Pada hari ke-2, laju perlakuan kontrol dan $\mathrm{NaNO}_{3}$ meningkat $7-9 \%$ dengan $\mathrm{NaNO}_{3}$ masih yang tertinggi sedangkan yeast extract naik sekitar $2 \%$. Pada hari ke-3 dan 4 laju degradasi pada kontrol secara konsisten naik di kisaran 4\% hingga mencapai $31,15 \% . \mathrm{NaNO}_{3}$ dan yeast extract hanya mengalami sedikit kenaikan dengan laju degradasi akhir masing-masing 25,68\% dan 21,86\%.

\section{Pembahasan}

\section{Isolasi Pseudomonas sp. BOT4}

Anggota genus Pseudomonas terutama Pseudomonas aeruginosa telah lama diaplikasikan dalam biodegradasi karena dapat menghasilkan biosurfaktan menggunakan berbagai substrat untuk pertumbuhannya salah satunya minyak jelantah. Isolat Pseudomonas sp. BOT4 dalam penelitian ini diambil dari lingkungan tercemar minyak jelantah dengan asumsi isolat mampu menggunakan minyak sebagai substrat pertumbuhan dan bakteri tersebut dapat mendegradasi minyak.

Karakter isolat dideterminasi sesuai panduan Brenner et al., (2005) setelah ditumbuhkan dalam medium Cetrimide sebagai medium selektif untuk Pseudomonas spp. Hasil determinasi menunjukkan beberapa karakteristik khusus yang dimiliki oleh Pseudomonas spp. (Tabel 1). Uji gelatinase 
bertujuan untuk melihat kemampuan bakteri dalam menghasilkan enzim gelatinase yang mampu menghidrolisis gelatin (Priharta, 2008). Beberapa mikroorganisme dapat menguraikan molekul gelatin menjadi asam amino dan kemudian mampu menggunakannya sebagai sumber energi yang digunakan dalam metabolisme. Struktur utama gelatin adalah gel dan gelatin yang telah dimetabolisme sempurna oleh bakteri tidak berbentuk gel dan lebih bersifat cair (Lay, 1994).

Satu karakteristik dasar yang paling berhubungan dengan penelitian yaitu sifat lipolitik yang dimiliki isolat melalui uji lipolitik sebelum isolat dijadikan inokulum untuk uji degradasi minyak jelantah. Hasil uji lipolitik dilihat dari nilai indeks lipolitik yang dihitung berdasarkan perbandingan diameter kertas cakram dan zona bening yang terbentuk pada medium. Isolat dengan kode BOT4 diketahui memiliki nilai indeks lipolitik tertinggi dengan nilai 12,91. Mikroba seperti Pseudomonas yang telah diketahui mampu menghasilkan lipase diyakini juga mampu menghasilkan biosurfaktan karena proses sintesinya bekerja melalui mekanisme genetik yang sama (Heurlier et al., 2004).

\section{Kepadatan Sel Pseudomonas sp. BOT4}

Hubungan antara kepadatan sel dan waktu pertumbuhan dinyatakan dalam kurva absorbansi (Gambar 2). Pada penelitian ini, kurva absorbansi Pseudomonas sp. BOT4 dalam tiap perlakuan diamati dengan mengukur nilai OD (optical density) atau laju kekeruhannya menggunakan spektrofotometer UV-Vis pada panjang gelombang $600 \mathrm{~nm}$ setiap hari selama empat hari. Kepadatan sel berkaitan dengan pertumbuhan bakteri yaitu terjadinya penambahan kuantitas sel bakteri baik terutama dalam hal jumlah dan massa sel (Pelczar \& Chan, 2005). Pertumbuhan dapat diamati dengan meningkatnya kepadatan atau kekeruhan kultur dalam rentang waktu tertentu dibandingkan kondisi awal. Rodrigues et al. (2006) menyatakan bahwa pertumbuhan sel dan akumulasi produk metabolit (termasuk biosurfaktan) dipengaruhi oleh komposisi media seperti sumber karbon, sumber nitrogen, faktor pertumbuhan dan garam-garam inorganik.

Inokulum yang digunakan dalam penelitian sebanyak $2 \mathrm{~mL}$ atau dengan rasio sekitar 3\%. Hal ini dimaksudkan untuk menekan timbulnya efek penghambat pertumbuhan berupa media yang keruh akibat sel yang terlalu padat karena efek penghambat meningkat dengan meningkatnya rasio inokulum. Rasio inokulum yang rendah dapat memperpanjang fase pertumbuhan bakteri yang lambat, sementara rasio inokulum yang tinggi dapat menyebabkan pembatasan zat gizi dan oksigen. Selain rasio inokulum juga diperhatikan mineral yang digunakan dalam medium. Penambahan unsur mineral dimaksudkan untuk menstimulasi akumulasi metabolit. Akan tetapi jika terdapat dalam konsentrasi tinggi mineral dapat menimbulkan efek penghambat yang terutama disebabkan oleh tekanan osmotik karena sel bakteri mengalami dehidrasi sehingga berakibat pada penghambatan pertumbuhan dan kematian sel (Zou et al., 2014; Nichols et al., 2000).

Kurva kepadatan sel seperti yang ditunjukkan pada Gambar 2 menggambarkan pola secara umum kepadatan sel bakteri seluruh perlakuan yang cenderung meningkat pada hari pertama, kedua, dan ketiga dan menurun pada hari keempat. Kepadatan sel pada kontrol dan yeast extract meningkat bertahap pada hari pertama dan kedua sementara kepadatan meningkat lambat pada $\mathrm{NaNO}_{3}$ pada hari pertama meski kemudian meningkat cukup signifikan pada hari kedua. Hal ini diduga dapat dikarenakan adaptasi sel bakteri pada $\mathrm{NaNO}_{3}$ yang cukup lama pada hari pertama dibandingkan dengan Kontrol dan yeast extract. Kepadatan sel mencapai puncaknya pada hari ketiga saat seluruh sel aktif membelah. Pada hari keempat seluruh perlakuan mengalami penurunan kepadatan sel utamanya diduga dikarenakan penurunan kadar nutrien dan penumpukan metabolit dalam medium yang dapat bersifat toksik. Penurunan ini juga dapat disebabkan oleh penurunan kadar oksigen untuk pertumbuhan karena Pseudomonas umumnya membutuhkan oksigen secara intensif (Panesar et al., 2009).

Berdasarkan Gambar 2, dapat dilihat bahwa pada hari ke-3 seluruh perlakuan mengalami puncak kepadatan sel yaitu perlakuan yeast extract memiliki kepadatan tertinggi $\left(\mathrm{OD}_{600}=2.300\right)$ diikuti $\mathrm{NaNO}_{3}\left(\mathrm{OD}_{600}=1.361\right)$ dan Kontrol $\left(\mathrm{OD}_{600}=0.907\right)$. Hal ini didasarkan pada hasil penelitian oleh Qazi et al. (2013) yang menyatakan bahwa yeast extract meskipun termasuk sumber nitrogen organik tetapi yeast extract juga mengandung protein, karbohidrat, asam amino, dan nukleat. Oleh karena itu, yeast extract tidak hanya mengandung nitrogen tetapi juga karbon sehingga terdapat lebih banyak energi untuk pertumbuhan bakteri. Dengan demikian jumlah dan massa sel bakteri dalam kultur yeast extract lebih banyak dibanding dengan kultur lain.

\section{Berat Minyak Jelantah Terdegradasi}

Degradasi minyak jelantah ditunjukkan dengan adanya residu minyak jelantah sebagai penanda adanya penurunan kandungan minyak dalam medium setelah diberi perlakuan. Data selisih antara berat awal dan berat akhir minyak tiap perlakuan 
dijadikan dasar untuk menentukan ada tidaknya pengaruh penambahan sumber nitrogen $\left(\mathrm{NaNO}_{3}\right.$ dan yeast extract) terhadap degradasi minyak.

Pada hasil dapat dilihat bahwa $\mathrm{NaNO}_{3}$ efektif pada dua hari pertama dan perlakuan kontrol efektif pada dua hari terakhir dengan perbedaan persentase laju akhir yang cukup besar. Hal ini menunjukkan bahwa penambahan $\mathrm{NaNO}_{3}$ hanya berpengaruh pada dua hari pertama degradasi dan cenderung stagnan pada dua hari berikutnya. Berbeda dengan kontrol yang tanpa penambahan nitrogen, meskipun lebih lambat pada awal degradasi tetapi tetap meningkat secara signifikan pada dua hari terakhir. Hal ini didukung oleh Syldatk et al. (1985) yang menyatakan bahwa limitasi nitrogen berperan penting pada peningkatan produksi biosurfaktan atau dalam kasus ini menunjukkan bahwa ketidaktersediaan nitrogen ternyata lebih cepat menginisiasi produksi biosurfaktan sehingga proses degradasi terjadi lebih efektif meski belum dapat dipastikan apakah mekanisme degradasi yang terjadi pada kontrol sama dengan mekanisme yang terjadi jika digunakan sumber nitrogen.

Sumber nitrogen $\mathrm{NaNO}_{3}$ diketahui hanya mengandung nitrogen tanpa tambahan kandungan karbon. Setelah bakteri menggunakan sumber karbon dan sumber nitrogen untuk pertumbuhannya, bakteri langsung mulai membentuk rhamnolipid. Dengan demikian meski dalam perlakuan kepadatan yang dihasilkan lebih kecil tetapi aktivitas degradasi yang terjadi lebih efektif. Beberapa penelitian yang berfokus pada produksi biosurfaktan menyatakan bahwa nitrat merupakan sumber nitrogen terbaik untuk produksi biosurfaktan (Arino et al., 1996; Robert et al., 1991; Mulligan \& Gibbs, 1989) tidak ditemukan dalam penelitian ini.

Berbeda dengan kontrol dan $\mathrm{NaNO}_{3}$, meski yeast extract menunjukkan kepadatan yang paling tinggi (Gambar 3), tetapi menunjukkan laju biodegradasi yang paling rendah yaitu nilai residu minyaknya paling sedikit dibandingkan perlakuan lain. Penggunaan sumber nitrogen organik salah satunya yeast extract, memang lebih memberikan pengaruh signifikan terhadap pertumbuhan sel dibanding pengaruh dalam produksi rhamnolipida (Moussa et al., 2014; Kim et al., 2006). Meski yeast extract merupakan sumber nitrogen yang paling sering digunakan untuk produksi biosurfaktan (Amaral et al., 2008), penelitian Rashedi et al. (2006) malah menunjukkan penggunaan yeast extract tidak dianjurkan dalam produksi biosurfaktan. Hal ini terkait dengan sifatnya yang kompleks karena dapat berperan sebagai sumber karbon selain sumber nitrogen sehingga menyebabkan penumpukan polisakarida meski nitrogen yang menipis. Qazi et al. (2013) menyatakan bahwa yeast extract yang mengandung gugus amina dapat memicu terjadinya sintesis biosurfaktan yang mengandung peptid (seperti lipopeptid) atau merangsang pertumbuhan enzim yang mengatur sintesis jenis biosurfaktan lainnya.

Biosurfaktan dapat diproduksi jika terjadi akumulasi lemak pada dinding sel bakteri. Bakteri akan mengakumulasi lebih banyak lemak jika terdapat sedikit nitrogen dalam media. Lemak merupakan hasil metabolisme lanjut dari karbohidrat yang terjadi karena kebutuhan nitrogen dalam sel dalam jumlah yang terbatas yang digunakan untuk sintesis protein seluler. Mikroba yang menghadapi kondisi pertumbuhan dengan kadar nitrogen terbatas melakukan konversi gliserol menjadi rhamnolipid (Nugroho, 2006). Faktor lainnya yang dapat mempengaruhi produksi biosurfaktan adalah jenis nutrien, temperatur, $\mathrm{pH}$, dan aerasi (Kosaric et al., 1983).

Berdasarkan penjelasan di atas diperoleh kesimpulan penggunaan sumber nitrogen baik $\mathrm{NaNO}_{3}$ maupun yeast extract kurang memberikan pengaruh yang signifikan dalam berat minyak jelantah terdegradasi yang dihasilkan meskipun lebih memberikan pengaruh yang signifikan (terutama sumber nitrogen yeast extract) terhadap kepadatan sel Pseudomonas sp. BOT 4.

\section{DAFTAR PUSTAKA}

Amaral, PFF, Coelho, MAZ, Marrucho, IM, \& Coutinho, JAP, 2008, 'Biosurfactants from Yeasts: Characteristics, Production and Application', Biosurfactants, Landes Bioscience, Dept. of Chemistry, University of Aveiro, Aveiro, Portugal

Arino, S, Marchal, R, \& Vandecasteele, JP, 1996, 'Identification and production of a rhamnolipidic biosurfactant by a Pseudomonas species,' Appl. Microbiol. Biotechnology, 45: 162-168

Bestari, NC \& Suharjono, 2015, 'Uji Kualitatif dan Kuantitatif Isolat Bakteri Lipolitik dari Limbah Cair Pabrik Pengolahan Ikan Kecamatan Muncar, Banyuwangi', Jurnal Biotropika 3 (3)

Bharathi, P, Elavarasi, N, \& Mohana Sundaram, S, 2012, 'Studies on Rate of Biodegradation of Vegetable (Coconut) Oil by Using Pseudomonas aeruginosa', International Journal of Environmental Biology 2 (1): 12-19 
Boulton, CA \& Ratledge, C, 1987, 'Biosynthesis of Lipid Precursors to Surfactant Production', Biosurfactants and Biotechnology 47-87

Brenner, DJ, Krieg, NR, Staley, JT, Garrity Sc.D, GM, Boone, DR, Vos, PD, Goodfellow, M, Rainey, FA, \& Schleifer, KH, 2005, Bergey's Manual of Systematic Bacteriology Volume 2: The Proteobacteria, Part B: The Gammaproteobacteria, ISBN 9780387280226, Springer US

Dalynn Biologicals, 2014, 'McFarland Standard - for in vitro use only', Catalogue No TM50-TM60

Daulay, SS \& Madya, W, 2015, 'Pengembangan Minyak Kelapa', Karya Tulis Ilmiah Hasil Survei, Kementerian Perindustrian Republik Indonesia

Heurlier, K, Williams, F, Heeb, S, Dormond, C, Pessi, G, Singer, D, Camara, M, Williams, P, \& Haas, D, 2004, 'Positive Control of Swarming, Rhamnolipid Synthesis, and Lipase Production by the Posttranscriptional RsmA/RsmZ System in Pseudomonas aeruginosa PAO1', Journal of Bacteriology, 186 (10): 2936-2945

Kim, HS, Jeon, JW, Kim, BH, Ahn, CY, Oh, HM, \& Yoon, BD, 2006, 'Extracellular Production of a Glycolipid Biosurfactant, Mannosylerythritol Lipid, by Candida sp. SY16 Using Fed-batch Fermentation', Appl. Microbiol. Biotechnol., 70,391

Kosaric, N, Neil, CC, Gray, \& Cairns, WL, 1983, 'Microbial emulsifiers and de- emulsifiers' dalam H.J. Rehm and G. Reed, Biotechnology, 3 Verlag Chemie.

Lay B, 1994, Analisis Mikrobia di Laboratorium, PT. Grafindi Persada, Jakarta

Lessard, P \& Le Bihan, Y, 2003, Introduction to Microbiological Wastewater Treatment, Fixed Film Processes, Handbook of Water and Wastewater Microbiology, Ed Duncan Mara and Hogan Elsevier hal 317-336

Lysenko, O, 1961, 'Pseudomonas - An attempt at a general classification', Microbiology 25: 379408

Moussa, TAA, Mohamed, MS, \& Samak, N, 2014, 'Production and Characterization of DiRhamnolipid Produced by Pseudomonas aeruginosa TMN,' Brazilian Journal of Chemical Engineering, 31 (04): 867-880

Mulligan, CN \& Gibbs, BF, 1989, 'Correlation of Nitrogen Metabolism with Biosurfactant Production by Pseudomonas aeruginosa',
Applied and Environmental Microbiology, 55 (11): 3016-3019

Nichols, DS, Olley, J, Garda, H, Brenner, RR, \& McMeekin, TA, 2000, 'Effect of Temperature and Salinity Stress on Growth and Lipid Composition of Shewanella gelidimarina', Appl. Environ. Microbiol. 66 (3): 2422-2429

Noegroho, H, 1999, 'Pengaruh Aerasi pada Bioproses Limbah Kilang Minyak', Lembaran Publikasi Lemigas 2: 20-24

Nugroho, A, 2006, 'Produksi Biosurfaktan oleh Bakteri Pengguna Hidrokarbon dengan Penambahan Variasi Sumber Karbon', Biodiversitas. 7 (4): 312-316

Panesar, R, Panesar, PS, Hasija, D, Bera, M. B, \& Kumar, H, 2009, 'Fermentative Potential of Pseudomonas aeruginosa Strain for Biosurfactant Production', Biol. Forum. Inter. J., 1,109

Pelczar, M.J \& Chan, ECS, 2005, Dasar-dasar Mikrobiologi 1, Alih bahasa: Hadioetomo, RS, Imas, T, Tjitrosomo, SS dan Angka, SL, UI Press, Jakarta

Priharta, AAYD, 2008, 'Isolasi dan Identifikasi Bakteri Endofit dalam Batang Tanaman Artemisia annua L. yang Diuji Potensi Antibakterianya terhadap Eschericia coli dan Staphylococcus aureus. Skripsi Universitas Sanata Darma Yogyakarta

Pusat Data dan Sistem Informasi Pertanian, 2015, Statistik Konsumsi Pangan 2015, Diakses pada 03 November 2017 di http:// epublikasi.setjen.pertanian.go.id/epublikasi/Sta tistikPertanian/2015/STATISTIK\%20KONSU MSI\%20PANGAN\%202015/files/assets/basich tml/page114.html

Qazi, MA, Malik, ZA, Qureshi, GD, Hameed, A, \& Ahmed, S, 2013, 'Yeast Extract as the Most Preferable Substrate for Optimized Biosurfactant Production by rhlB Gene Positive Pseudomonas putida SOL-10 Isolate', Journal of Bioremediation \& Biodegradation, 4 (7) ISSN: 2155-6199

Ramdja, AF, Febrina, L, \& Krisdianto, D, 2010, 'Pemurnian Minyak Jelantah Menggunakan Ampas Tebu sebagai Adsorben', Jurnal Teknik Kimia Universitas Sriwijaya 17: 7-14

Rashedi, H, Jamshidi, E, Assadi, MM, \& Bonakdarpour, B, 2006, 'Biosurfactant Production with Glucose as a Carbon Source', Chem. Biochem, Eng Q, 20 (1): 99-106 
Robert, M, Mercadé, ME, de Andrés, C, Espuny, M.J, Manresa, MA, \& Guinea, J, 1991, 'Optimización de la producción de biotensoactivos por Pseudomonas aeruginosa 44T1', Fasc. 1, 42: 1-7

Rodrigues, L, Teixeira, J, Oliveira, R, \& van Der Mei, HC, 2006, 'Response surface optimization of the medium components for the production of biosurfactants by probiotic bacteria', Process Biochemistry. 41: 1-10

Silva, RMP, Rodriguez, AA, de Oca, JMGM, \& Moreno, DC, 2006, 'Biodegradation of Crude Oil by Pseudomonas aeruginosa AT18 Strain', Tecnhnologia Quimica 26 (1): 70-77

Subasioglu, T \& Cansunar, E, 2008, 'Nutritional Factors Effecting Rhamnolipid Production by a Nosocomial Pseudomonas aeruginosa', Hacettepe Journal of Biology and Chemistry 36 (1): 77-81

Syldatk, C, Lang, S, Wagner, F, Wray, V, \& Witte, L, 1985, 'Chemical and physical characterization of four interfacial-active rhamnolipids from Pseudomonas spec. DSM 2874 grown on nalkanes', Z. Naturforsch 40 (1-2): 51-60

Todar, K, 2004, Todar's Online Textbook of Bacteriology: Pseudomonas aeruginosa, Department of Bacteriology, Univ. of Wisconsin-Madison

Wu, JY, Yeh, KL, Lu, WB, Lin, CL, \& Chang, JS, 2008, 'Rhamnolipid Production with Indigenous Pseudomonas aeruginosa EM1 Isolated from Oil Contaminated Site', Bioresour. Technol., 99,1157

Zou, CJ, M, Wang, Y, Xing, G, Lan, TT, Ge, X, Yan, \& $\mathrm{T}$, Gu, 2014, 'Characterization and Optimization of Biosurfactants Produced by Acinetobacter baylyi ZJ2 Isolated from Crude Oil-contaminated Soil Sample toward Microbial Enhanced Oil Recovery Applications', Biochem. Eng. J. 90 (10): 49-58 